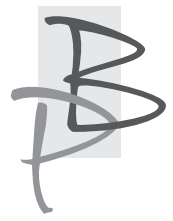

\title{
Olesia Medynska*
}

Department of Journalism Ternopil Volodymyr Hnatiuk National Pedagogical University (Ukraine)

https://orcid.org/0000-0002-3769-163X

\section{Markiian Medynskyy**}

Medical department I. Horbachevskyi Ternopil State Medical University (Ukraine) https://orcid.org/0000-0002-0290-9053

\section{Historical discourse of the chronicle novel „The Vanishing Shadows. A Family Chronicle Shadows" by Valeriy Shevchuk}

Summary: The article presents a study of the historical foundations of the chronicle novel "The Vanishing Shadows. A Family Chronicle" by Valeriy Shevchuk. The attention is focused on the writer's interpretation of historical events in the late $18^{\text {th }}$ century. The social and ideological, discursive processes of the reproduced historical period are analyzed. An integral perception of the history of our country is presented in an inseparable connection between the past and the present. The critical moments in Ukrainian history were outlined as the background against which some urgent, vital problems of either a single individual or the whole ethnic group were shown. Particular characters are correlated with the historical figures, with historical truth being confirmed both in

* Olesia Medynska - doktor nauk filologicznych, wykładowca Katedry Dziennikarstwa (Tarnopolski Narodowy Uniwersytet Pedagogiczny im. Włodzimierza Hnatiuka, Tarnopol, Ukraina). Zainteresowania badawcze: historia literatury ukraińskiej XX wieku, mitologia, myślenie krytyczne i technologie jego kształtowania. Publikacje: Znaki kultury książki w powieści-kronice Wałerija Szewczuka „Znikajace cienie” (Brno 2015); Gatunkowo-kompozycyjne inwarianty powieści-kroniki Wałerija Szewczuka „Znikające cienie” (Tarnopol 2013); Problem ludzkiej egzystencji w refleksjach filozoficznych W. Szewczuka i T. Manna (München 2016).

$* *$

Markiian Medynskyy - student Wydziału Medycznego (Państwowy Uniwersytet Medyczny im. Iwana Gorbaczewskiego, Ministerstwo Zdrowia Ukrainy, Tarnopol, Ukraina). Zainteresowania badawcze: współczesna literatura ukraińska. 
details and in the general picture of represented reality. Special stress is placed on the artistic depiction of intrinsic motives of the members of the ancient noble family of Temnytskyi. The article discusses the issues of nation-building in the context of social destruction and imperial enslavement. We also propose a new paradigm of human spiritual existence that was inspired by Schevchuk's work, and explore the ideas of national self-identification as a spiritual rather than caste community, and of the quest for national unity embarked on by intelligentsia as the leader of the nation.

Key words: historical discourse, chronicle novel, national identity, intentions.

\section{Dyskurs historyczny powieści-kroniki Wałerija Szewczuka Zni- kające cienie}

Streszczenie: Artykuł zawiera analizę dzieła Wałerija Szewczuka pt. Znikające cienie. Badaczy interesują przede wszystkim takie wartości, jak kontekst historyczny, w jakim osadzono fabułę, jak również wszelkie dostrzegalne procesy ideologiczne i społeczne. Historię Ukrainy Szewczuk ukazuje na szerokim tle, wypunktowując najważniejsze momenty krytyczne w historii tego państwa, gdy pojawiały się i znikały najbardziej wyraziste problemy pojedynczego człowieka oraz całego narodu jako ogółu.

Słowa-klucze: dyskurs historyczny, powieść-kronika, tożsamość narodowa, intencje.

Valeriy Shevchuk is an outstanding representative of Ukrainian culture in the second half of the 20th and early 21 st century, who laid the systemic artistic and scientific foundations of the new national spiritual and aesthetic model to be applicable to a wide range of activities pertaining to such domains as ideology, historiosophy, science, literature, art, and journalism.

The writer embarked on his creative path in the 1960's, which contributed to the shaping of his view of the world - involving the historical situation of the Ukrainians, and a transition from the schemata of totalitarian thinking with 
the resulting herd mentality to the focus on personal individuality Shevchuk redefined the values fostered and enhanced by totalitarian ideology, denied the monistic perspective with its "plain picture of the world", and went deeper into the spiritual space of the soul of his nation. He created an individual intellectual and aesthetic discourse that triggered changes in the social and aesthetic consciousness.

The works by Valeriy Shevchuk were investigated and discussed by many scholars. Attempts to objectively comprehend the writer's prose are found in the literary-critical articles by Stefaniia Andrusiv, Mykola Riabchuk, Mykhailo Slasboshpytskyi, Raisa Movchan, Larysa Zalevska-Onyshkevych. A thorough analysis of some aspects of the creative work of the artist is presented in the publications of Marko Pavlyshyn, Roman Korohodskyi, Anna Horniatko-Shumylovych. The study by Olesia Medynska is devoted to the nature of the artistic explication of the national mode in the chronicle novel "The Vanishing Shadows" and in the general ideological and aesthetic strategy of Valeriy Shevchuk. The peculiarities of the artistic model of national identity, the onyric-mythological discourse of the writer's prose were focused on by Larysa Donchenko, Tetiana Zhovnovska, and others. However, since this wide array of literary research, deals only with some specific aspects of Shevchuk's writing, there may still be problems that remain unexplored. In this context it seems crucial to scrutinize the historical basis of the novel "The Vanishing Shadows" (named a "family chronicle" by Shevchuk himself), since history is an integral organic and artistic part of the plot and defines the writer's idiostyle.

The objective of the present study is to reveal the unique features of historical discourse the chronicle novel "The Vanishing Shadows" by Valeriy Shevchuk.

Valeriy Shevchuk's prose is multidimensional, versatile, and traces the intellectual and spiritual development of the Ukrainian people, the dialectic of their soul from pre-Christianity till modern times. In the artistic discourse the writer articulates the ideological and artistic vectors of the new paradigm of human knowledge: the depiction of personality as a subject of Ukrainian history in the broadest sense of the concept. This brings Ukrainian culture into the paradigm of the world, creating the „humanitarian aura of the nation” (Lina Kostenko) in the reception of the world community. 
In the continuum of the writer's works, the novel "The Vanishing Shadows" is updated, sublimating the previous artistic and scientific achievements and simultaneously opening new facets of his talent. The work is an integral part of the whole architectural scientific and artistic construct of the writer, depicting the millennial history of the national mysteries of the Ukrainian intelligentsia and the common people.

As Valeriy Shevchuk notes, "The Vanishing Shadows” is an „unusual type of historical novel in Ukrainian literature. This is a family chronicle of one of the Ukrainian families"1. According to the writer, the reason for this genre spreading is the following:

$[\ldots]$ in our many years of statelessness, because the truth is generally recognized: there is no state, there are no glorious ancestries. Therefore, perhaps, the representatives of the generations deeply rooted in the past, so often went to serve the state that conquered their land: they adapted themselves to stay alive and exist, and thereby indirectly condemned themselves to death $[\ldots]^{2}$.

The novel "The Vanishing Shadows" is an artistic interpretation of the complex and insufficiently highlighted problems in the history of Ukraine, that is the search for the national identity in the second half of the $18^{\text {th }}$ and the beginning of the $19^{\text {th }}$ centuries. It was then that, after a long period of stagnation, the Ukrainian resistance movement was ripening. Ivan Lysiak-Rudnytskyi noted that:

[...] the history of Ukraine, one of the most interesting facets of the European and world history, was interpreted by our researchers as a peripheral annex to the Russian history; it was reduced to a predominantly recent period and was limited to a few textbook episodes. Those social models and values that enriched or could have enriched the world experience of democratic self-organization of people were particularly stubbornly and cunningly ignored $[\ldots]^{3}$.

1 V. Shevchuk, Tini znykomi. Simejna xronika, Tempora, Kyyiv 2002, s. 2.

2 Tegoż, Mali ukrayinski litopysy, xroniky ta diariushi, "Kyyivska starovyna" 1993, Issue 6, s. 18 .

3 I. Lysyak-Rudnyczkyj, Istorychni ese: u 2 t., Osnovy, Kyyiv 1994, Vol. 1, s. 94. 
On the basis of literary works and documents of many epochs, real facts about the life of the contemporary Ukrainian (Cossack) starshyna (senior officers) and didyches (landlords), in whose consciousness the desire to find not only their spiritual but also their ethnic essence was reviving. Valeriy Shevchuk put to the forefront the deep nation-building intentions that were emerging in the period in question. In his scholarzy works Orest Subtelnyi gave a description of the transition of Ukrainian intellectuals from "malorossiistvo" (Little Russian identity) to Ukrainian identity, which is echoed in the aesthetic manifestation of this problem and in the novel "The Vanishing Shadows":

If you ask what induced them to such esoteric practices as the collection of ancient documents, rare folk songs or imitation of the peasant dialect, many intellectuals would have explained this as a kind of hobby caused by local patriotism and nostalgia for the disappearing world. Nevertheless, as a result of these early, amateur studies, a small group of educated Ukrainians has a unanimous view on what should be considered as the fundamental elements of Ukrainian culture itself. Soon these findings will become the basis of Ukrainian national consciousness ${ }^{4}$.

In line with this understanding of national intentions Valeriy Shevchuk builds the historical basis of the novel "The Vanishing Shadows", and, consequently, the whole of its artistic construction. Ukrainian history in all its philosophical dimensions, moral and ethical extremes, appears in the book as the general human background. The writer's literary virtuosity and his philosophical thinking made the represented world of the past reflect the problems of the present. This is due to the fact that the author used his own scientific research of the little-known period of the birth of the new Ukrainian Renaissance in the late $18^{\text {th }}$ century in the making of the historical basis of the novel.

The chronotype of the book is the end of the eighteenth century, when the last traces of Ukrainian autonomy within the Russian Empire disappeared. The last Hetman of Ukraine, Kyrylo Rozumovskyi, renounced his title. The Zaporizhian Sich, the symbol of Ukraine's military and national power, was liquida- 
ted, and serfdom was introduced. Due to the repressive measures of Catherine II, Ukraine was degraded to the level of a Russian province. The situation was complicated by the first partition of Poland: those who wished to stay on their land, lost their right to estate. These events left their mark on the protagonists of the novel, the Temnitskyi family. "My ancestors of the ancient gentry..."5, observes Theodosius Temnitskyi, who found his roots in the "Polish Coats of Arms", tracing his descent back to the year 1062. The generic coat of arms (an arrow pointing downward, shot onto the ground) acquired consistently "new signs and symbols" until the "two-headed eagle" flew to the top of the father's coat of arms. In the history of Ukraine, the Temnytski:

[...] burst in the second half of the XVIIIth century as colonels of the Zaporozhian Army; moreover, the King John Casimir added the armour over the shield, crowned with a noble crown to Vasyl and Kyryl. Consequently, the Polish Crown and the two-headed eagle determined the temporary service to the states, ...but the main thing remained unchanged, the arrow, or maybe the land onto which it was shot $[\ldots]^{6}$.

And this, in the opinion of the protagonist/author, is "neither Poland and nor Velykorossia (Great Russia), but the one on which I saw and got to know the world and with which the arrow on the ground is connected - all my kin... I lived in a space that was called differently: Rus', Malorossiia, Ukraine"7.

At that time, Ukraine lost its traditional elite, which should have played a significant role in creating a national one. However, the contours of a nationwide project had already existed, especially at the level of political instinct of prominent figures or collective subconscioussness of the common people.

With all the disparity of figures, political styles, strategies, scope of victories and defeats, intellects and temperaments, everyone worked on defining the fate

5 V. Shevchuk, Tini znykomi. Simejna xronika, Tempora, Kyyiv 2002, s. 65.

6 Tamże, s. 7.

7 Tamże. 
of not only the Cossack state, but the Ukrainian people in all its ethnic and social completeness ${ }^{8}$.

The diversity and unity of these efforts - from hetmans, starshyna, didyches to the common people - appear in the works by Valeriy Shevchuk. "The Vanishing Shadows", reproduced mixed reactions of the Ukrainians towards these events. Some of the officers, landlords, intellectuals had great hopes and expectations of an integral whole with Russia, seeking to equalize their status with that of the Russian nobility. The Russian Empire needed specialists in various areas of administrative activity, where Ukrainian intellectuals reasonably believed themselves (and they actually were) culturally higher than Muscovites and were not afraid of competition. They established a translation department of the foreign affairs office, they were leading economists (Semen Desnytskyi, Mykhailo Livanov), well-known artists (Dmytro Levytskyi, Anton Losenko, Volodymyr Borovykovskyi), sculptors (Ivan Martos), composers (Dmytro Bortnianskyi, Artem Vedel, Maksym Berezovskyi), writers [Ivan Bohdanovych, Mykola Hnedych (Hnidych), Vasyl Kapnist], well-known statesmen (Oleksandr Bezborodko, Dmytro Troshchynskyi, Petro Zavadovskyi). A Ukrainian prelate Theophanes Prokopovych presented a complete scientific justification of the modern model of secular monarchy. Even the fierce chauvinists admitted that it was Ukraine that had pushed Moscow to the path of social transformation: it awakened the predecessors of Peter I and prepared the ground for his reforms. Realizing its intellectual potential in Russia, the Ukrainian elite did not make any efforts to help Ukraine develop, their cooperation with a foreign state caused intellectual stagnation in their native territories. In the Empire, on the other hand, the cultural and social revolutionary ideas inspired by Peter I were beginning to disseminate. No similar processes took place in Ukraine, where culture did not come under the auspices of the church, and national self-awareness remained only as an idea.

The key problem of Ukraine's intellectual history, in particular its opposition to Russia, was the internal renegade of the intellectual elite, the loss of its "home of the fatherland" (Stefaniia Andrusiv), its separation from the common people, the lack of state leadership, the spiritual amnesia. A generic feature of

8 M. Slaboshpyczkyj, Mozhlyvosti «vyspovidalnogo» j eksperymentalnogo pysma, "Literaturni profili: Literaturno-krytychni narysy”, Ukrayinskyj pysmennyk, Kyyiv 1984, s. 208. 
the historical intelligentsia was the feeling that national hopes died out, and this was projected into its consciousness, thereby "weakening the will to act" (Valeriy Shevchuk). Mykola Kostomarov presented his panorama of spiritual destruction of the enslaved Ukraine as follows:

Ukrainian affair had clearly perished. People had lost faith in their cause, in their purpose. It was thought that the goal can not be achieved at all. Because of this, the will and patience disappeared, love for the native land, the public good weakened. The patriotic acts and victims were futile. Private personal interests dominated over all honest and patriotic impulses. Everything that was once expensive, sacred, now was sold every time cheaper. The hero of the time was considered to be one who, among the general disturbance, was able to save himself, to escape from the marshes of anarchy, having sink another, securing himself 9 .

And although these words relate to the Khmelnytskyi period, their essence is still true...

In the storyline of "The Vanishing Shadows" the author often relied on historical retrospections, where historical facts appear in the context of the experiences of the Temnytskyi family. For example, Theodor's great-great-grandfather was among those who supported Ivan Mazepa. He was even among his confidants, executed completely secret orders and died in his service; his grandfather Petro Hryhorovych deliberately gave his sons to military and clerical service. He himself, having spent a lot of efforts, realized that he could not, as a son of a scribbled person, count on royal mercy in the form of an advantageous service, so he bought a piece of land on the border with Lithuania to settle there. He did not approve of his father's deed. Among the papers of his grandfather, Todos found his letter to an unknown person:

What did my father achieve, passionately loving his homeland and putting his good name and his head for it, completely forgetting about the well-being of his own family? As a confidant of Machiavel (Mazepa), his deeds were devoured by

9 M. Kostomarov, Dve russkye narodnosty, „Osnova” 1861, Issue 3, s. 72. 
the time, the grave is in the middle of nowhere, he did not leave estates, he left the family ${ }^{10}$.

Subsequently, it turns out that these indictments were only for display, in fear of possible redraw of letters. For in fact, in the hiding places of the house (in his portrait in particular), the grandfather kept his father's confidential documents: copies of Mazepa's letters to the Polish King John III Sobieski about the possible restoration of the union on the basis of the Hadiach Treaty, the Constitution of Pylyp Orlyk and his own "The Removal of the Rights of Ukraine" and "Manifesto to European Rulers". There were also the letters of the grandfather to Dovhorukyi, Osterman, Queen Anna, Pototskyi, and Russian residents in Warsaw about the return of the confiscated estates to the greatgrandparents: "with numerous legal calls to the laws", in particular, presented in "Lithuanian Statute" by Hetman Danylo Apostol:

But all these gigantic measures weren't successful. By his decision, the Sejm has determined... that the Temnitskyi have no right to the estate of their ancestors, because they were dissidents, left Poland and began to serve in Russia11.

So Petro Hryhorovych was forced to serve, especially when the Hetman Apostle died, and his estates passed to the royal treasury. He rushed to the military service. And when he was able to begin building his "nest", the energy and vitality of traditions contributed to the fact that among the groves and centuries-old forest, the grandfather built Lesovychi, that soon became a village. An oak house, a school, a church, the choir of which he himself taught to sing, and the composer Vedel arrived here. "It was not just a house and a church and buildings with them - it was a settlement between the world of things that should become, or had already become, a part of yourself, soul and mind"12, - notes the author, pointing out to the main origins of the national renaissance.

Life struggles of the protagonists contribute to the condemnation of the Russian Empire as an invader. Almost all members of the Temnytskyi fami-

10 V. Shevchuk, Tini znykomi. Simejna xronika, Tempora, Kyyiv 2002, s. 71.

11 Tamże, s. 73.

12 Tamże, s. 95. 
ly participated in those wars, shedding blood for another country. Loyalty to a monarch whom one served was a measure of success in life. Losing one's soul was too high a price to pay. This was the theme of national renegade, abandoner, or even betrayer, pervades the whole novel and is manifested in a variety of conflicts.

What the reader may discover about "The Vanishing Shadows" is the writer's quest for the novel under discussion the philosophical meaningg of patriotism in its rational and irrational, concrete and mythological manifestations. Among the exisiting definitions of the concept of "national", it may seem that nationality in Valeriy Shevchuk's work is conceived of as very close to the definition given by Mykola Berdiaiev. The Russian philosopher with Ukrainian roots emphasized that "nationality appears to be mysterious, mystical, irrational, as well as every individual being"13.

In his historical and scientific studies Valeriy Shevchuk pays great attention to role of national elite, represented in "The Vanishing Shadows" in the figure of the protagonist. Describing the historical processes of nation-building, the writer notes:

I rely on the thesis of Ukrainian historian Viacheslav Lypynskyi about the nature of the state and state-building elite, which he considered in three states: the elite of warlords, the economic elite and the spiritual and cultural elite - all these three hypostases are connected in a system, the destruction of which leads to anomalies in the natural state-building process. Cementing enzyme for these elites, as well as for the integrity of national society, is a national consciousness, the appearance and assertion of which forms the prerequisite for the formation of the state elite itself ${ }^{14}$.

Describing the period depicted in "The Vanishing Shadow", the author, in particular, observes that in the martial Cossack society, even after Ivan Mazepa became a hetman, the military elite of starshyna actually replaced the social class of gentry, or aristocracy. The worries about the consolidation of estates

13 M. Berdyayev, Nacionalnist i lyudstvo, „Suchasnist” 1993, Issue 8-9, s. 150.

14 V. Shevchuk, Mali ukrayinski litopysy, xroniky ta diariushi, „Kyyivska starovyna” 1993, Issue 6, s. 19. 
started to appear. Since they were often dispensed not by ownership, but by rank, the elderly cared about the heredity of ranks in their families, which destroyed spirituality from the inside. Another factor that ruined Ukraine and contributed to the collapse was an enemy from the outside - the Russian state, which systematically destroyed the Cossack elite of Ukrainian warriors both physically and economically (the introduction of a Russian-controlled area that forced interest in claiming Russian citizenship).

Thus, in part of the starshyna - the owners of lands and estates, despite draconian methods of destroying Ukrainian autonomy, the attempt to keep Russian orientation does not disappear ${ }^{15}$.

The work depicts the contemporary position of the Ukrainian gentry, adapted to conditions or scribbled according to the national intentions, which, however, preserved the historical memory of glorious ancestors in their subconsciousness. Yurii Lytskyi provides a social and historical portrayal of their life:

This class was eliminated from the field of agiotage of bread products and trade operations. Its representatives could not, with rare exceptions, get the ranks of the highest bureaucracy. In the estate, the slow patriarchal landlord's life proceeded without any complaints about any kind of broad activity. Younger generations who were brought up in such a household environment often did not have the material opportunity to stay in the estate, but were forced to enter the service - the only way of the then-poor-nobles career. The position of a government official, a clerk in the capital, a military service with the achievement of a modest, low rank - these are the ideals of the livelihood, which could be sought and to which the young generations of the Ukrainian bourgeoisie actually went ${ }^{16}$.

The fact that not all lost the feeling of patriotism contributed to the growth of cultural movement in those days. Often, such tycoons like Bezborodko,

15 Tegoż, Nerozgadani tayemnyci «Istoriyi Rusiv», "Istoriya Rusiv”, Veselka, Kyyiv 2001, s. 35 .

16 Mala encyklopediya etnoderzhavoznavstva, ed. by I. Rymarenko, Geneza, Kyyiv 1996, s. 90. 
Repnin or Troshchynskyi, in search of their roots, actively supported gifted Ukrainian artists, providing them with moral and financial assistance.

According to researchers specializing in Ukrainian history in particular to Ivan Lysiak-Rudnytsky, the crucial factors for the loss of the national self-identity weren't

[...] the external above-mentioned events... as the internal revolution in the world view of then Ukrainian leading stratum, its refusal to further defend the political autonomy of the fatherland and the adoption of the decisive significance for the loss of national identity, and the acceptance of the All-Russian state ideology. Members of the privileged minorities agreed with the loss of the independent status of their native countries if they were compensated for by their career. This can be exemplified by Prince Bezborodko as Chancellor of the Russian Empire during the rule of Catherine II and Paul I [... $]^{17}$.

Their regional patriotism coexisted peacefully with „All-Russian”, imperial loyalty. However, "a gigantic galactic space between two worldviews: the traditional hierarchical and modern-democratic, imperial-regional and national, Little Russian and actually Ukrainian" 18 began to overcome ethnicity in the first half of the nineteenth century precisely because of those who had a sense of homeland responding to the atmosphere of the parents' home and the memory of their ancestors, or written family chronicles.

Gradually, the Little Russian elite entered a period of proto-nationalism. In his article titled "Ukrainian influence on Russian culture in 1750-1850", an Australian scientist David Saunders described this as follows:

Many people, not even being Ukrainian nationalists, expressed their Ukrainian identity. Having lost autonomy, they cherished the memory of it. Their views were conservative, but they gave material for inspiration to later Ukrainian nationalists ${ }^{19}$.

17 I. Lysyak-Rudnyczkyj, Istorychni ese: u 2 t., Osnovy, Kyyiv 1994, vol. 1, s. 197.

18 M. Ryabchuk, Knyga dobra i zla za Valeriyem Shevchukom, „Vitchyzna” 1988, Issue 2, s. 80.

19 D. Saunders, Ukrayinskyj vplyv na rosijsku kulturu 1750-1850, UVU, Edmonton 1985, s. 19. 
Discussing the philosophical manifestations of the national idea, Stefaniia Andrusiv referred to this phenomenon as "an attempt to create a vision of spiritual home after the loss of the home of their motherland" 20 . This is exactly what Valeriy Shevchuk communicates in "The Vanishing Shadows" through his portrayal of typical representatives of the Ukrainian nobility, the landlord family of Temnitskyi.

Thus, the basis of the novel "The Vanishing Shadows" are historical facts, especially those pertaining to the periods associated with the awakening of national consciousness. Valeriy Shevchuk creates a model of the Ukrainian world, where the value of each self-sufficient person is determined by the degree of their national identity. In this aspect, the main postulate of the writer's ideological concept is that the search for the spiritual will inevitably lead to national self-awareness, the awareness of the most important human mission is the building of the family in the "home of the motherland".

\section{Bibliografia}

Andrusiv S., Modus nacionalnoyi identychnosti: Lvivskyj tekst 30-x rokiv XX st., Lvivskyj nacionalnyj universytet imeni Ivana Franka, Dzhura, Lviv, Ternopil 2000. Berdyayev M., Nacionalnist i lyudstvo, „Suchasnist” 1993, Issue 8-9, s. 148-156. Kostomarov M., Dve russkye narodnosty, "Osnova” 1861, Issue 3, s. 61-83.

Luczkyj Yu., Mizh Gogolem i Shevchenkom, Chas, Kyyiv 1998.

Lysyak-Rudnyczkyj I., Istorychni ese: u 2 t., Osnovy, Kyyiv 1994, vol. 1.

Mala encyklopediya etnoderzhavoznavstva, ed. by I. Rymarenko, Geneza, Kyyiv 1996, s. 87-92.

Ryabchuk M., Knyga dobra i zla za Valeriyem Shevchukom, "Vitchyzna” 1988, issue 2, s. 76-179.

Saunders D., Ukrayinskyj vplyv na rosijsku kulturu 1750-1850, UVU, Edmonton 1985.

20 S. Andrusiv, Modus nacionalnoyi identychnosti: Lvivskyj tekst 30-x rokiv XX st., Lvivskyj nacionalnyj universytet imeni Ivana Franka, Dzhura, Lviv, Ternopil 2000, s. 12. 
Shevchuk V., Mali ukrayinski litopysy, xroniky ta diariushi, "Kyyivska starovyna" 1993, Issue 6, s. 17-20.

Shevchuk V., Muza Roksolanska: u 2 kn., Lybid, Kyyiv 2005, kn. 2.

Shevchuk V., Nerozgadani tayemnyci «Istoriyi Rusiv», „Istoriya Rusiv", Veselka, Kyyiv 2001, s. 7-51.

Shevchuk V., Tini znykomi. Simejna xronika, Tempora, Kyyiv 2002.

Slaboshpyczkyj M., Mozhlyvosti «vyspovidalnogo»j eksperymentalnogo pysma, "Literaturni profili: Literaturno-krytychni narysy", Ukrayinskyj pysmennyk, Kyyiv 1984, s. 197-216.

Subtelnyj O., Ukrayina: Istoriya, Lybid, Kyyiv 1993. 